\title{
Leukemia Inhibitory Factor (LIF) Stimulates Proopiomelanocortin (POMC) Expression in a Corticotroph Cell Line Role of STAT Pathway
}

\author{
David W. Ray, Song-Guang Ren, and Shlomo Melmed \\ Department of Medicine, Cedars-Sinai Research Institute-UCLA School of Medicine, Los Angeles, California 90048
}

\begin{abstract}
We recently described the expression of leukemia inhibitory factor (LIF) in human fetal and murine corticotrophs. LIF and the related cytokine oncostatin $M$ induced basal, and corticotropin-releasing hormone $(\mathrm{CRH})$ induced proopiomelanocortin (POMC) mRNA and ACTH secretion in AtT20 cells. LIF signaling and regulation of POMC gene transcription were therefore tested. Dexamethasone inhibited both basal- and LIF-induced ACTH secretion $(P<$ 0.05) and LIF induction of ACTH was also attenuated by immunoneutralization of either the LIF receptor $(35 \%, P<$ $0.05)$ or the gp130 affinity converter $(41 \%, P<0.05)$. These antisera also attenuated basal ACTH secretion in the absence of added ligand $(P<0.05)$. To examine intrapituitary LIF signaling, phosphorylation of post-receptor substrates was measured. $1 \mathrm{nM}$ LIF rapidly induced tyrosyl phosphorylation of STAT 1 and STAT 3 proteins, as well as tyrosyl phosphorylation of a $115-\mathrm{kD}$ protein, coimmunoprecipitated with STAT 1. The transfected rat POMC promoter $-706 /+64$, fused to the luciferase reporter gene, was induced by LIF, which exerted strong (18-fold) synergy with $\mathrm{CRH}$. Deletion of the major $\mathrm{CRH}$ responsive region in POMC (-323/-166) abolished CRH induction of transcription and severely limited LIF synergy. Although 8 bromo cAMP or forskolin modestly enhanced POMC transcription (2.8-fold), LIF markedly potentiated (7.4-fold) these cAMP activators. These results demonstrate that corticotroph LIF action is receptor mediated and involves activation of STAT signaling pathways. LIF potently synergizes with both $\mathrm{CRH}$ and CAMP induction of POMC transcription. This novel intrapituitary signaling mechanism may mediate a neuroimmune pituitary interface. (J. Clin. Invest. 1996. 97:18521859.) Key words: ACTH • cytokines • pituitary signaling • pituitary gene regulation • leukemia inhibitory factor
\end{abstract}

\section{Introduction}

The pituitary is an abundant source of several growth factors which also act as mediators of in vitro hormone production. In-

Address correspondence to Dr. Shlomo Melmed, Division of Endocrinology \& Metabolism, Cedars-Sinai Medical Center, 8700 Beverly Blvd., B-131, Los Angeles, CA 90048. Tel: 310-855-4691; FAX: 310967-0119.

Received for publication 10 October 1995 and accepted in revised form 24 January 1996.

J. Clin. Invest.

(C) The American Society for Clinical Investigation, Inc. 0021-9738/96/04/1852/08 \$2.00

Volume 97, Number 8, April 1996, 1852-1859 terleukins 1,2 , and 6 are detectable both in rodent and human pituitary tissue and in human pituitary tumors (1-3). Development and function of differentiated pituitary neuroendocrine cells are regulated both by hypothalamic trophic hormones and by intrapituitary cytokines and growth factors. These cytokines have been shown to stimulate the hypothalamic-pituitaryadrenal axis in vivo and pituicyte ACTH production (4-6).

The leukemia inhibitory factor $(\mathrm{LIF})^{1}$, originally isolated as an inhibitor of mouse-myeloid M1 cells, has been shown to be secreted by bovine pituitary monolayer cells (7) and we have recently demonstrated LIF gene expression in human fetal, adult, and murine pituitary cells (8). We have also shown that human fetal pituitary cells express high-affinity LIF binding (8). Murine pituitary AtT20 cells also express LIF binding sites and respond to LIF by increasing steady state levels of proopiomelanocortin (POMC) mRNA and ACTH peptide secretion (8). Expression of LIF and its binding sites varies among the human fetal pituitary cell populations, with the highest proportion of LIF-immunopositive cells being corticotrophs (8). In addition to these observations in human fetal pituitary, LIF immunoreactivity and receptor expression was also observed in normal and adenomatous pituitary tumor tissue removed at hypophysectomy (8). These data suggest an important role for LIF, both in normal pituitary development and in pituitary tumor pathogenesis.

LIF exerts its effects by activating specific target receptors. LIF receptors share a common receptor subunit, gp130, with the closely related oncostatin M (OSM) and also with ciliary neurotrophic factor, interleukin 11, interleukin 6, and cardiotrophin 1 (9-13). In addition, LIF, ciliary neurotrophic factor, and OSM also share the structurally related low affinity LIF-receptor beta subunit (14) which heterodimerises with gp130 to form a high affinity binding site (15). Ciliary neurotrophic factor signaling also requires an alpha subunit, as does IL-6. This subunit has a limited tissue distribution, thus determining selective tissue action (16). These diverse cytokines therefore retain their specificity of downstream intracellular action despite sharing common transmembrane receptor subunits.

The LIF-related cytokines likely act by stimulating activity of the JAK family of transmembrane receptor-associated tyrosine kinases (17). Subsequently, phosphorylation of signal transduction and activation of transcription (STAT) family members occurs $(18,19)$, which appears to be followed by translocation to the nucleus and participation in the assembly of a variety of transcription factor complexes (20-22). This JAK-STAT pathway has been linked to signaling by growth

1. Abbreviations used in this paper: $\mathrm{CNTF}$, ciliary neurotrophic factor; $\mathrm{CRH}$, corticotropin-releasing hormone; LIF, leukemia inhibitory factor; LIF-R, LIF-receptor; OSM, oncostatin M; POMC, proopiomelanocortin; STAT, signal transduction and activation of transcription. 
hormone (23), prolactin (24), erythropoietin, (25) and the interferons $(21,26-30)$.

LIF is a differentiation factor in a number of tissues, so its presence in fetal pituitary corticotrophs, and its previously demonstrated stimulation of ACTH production, suggest it may have a role in pituitary development. LIF and related cytokines exert divergent actions in diverse target tissues, raising the possibility that different intracellular substrates may be involved in signaling. The best characterized signaling molecules for this class of ligands are STAT 1 and STAT 3 and it is likely that additional STAT family members exist. Cytokine signaling typically leads to gene induction through specific cytokine response elements, but the POMC gene does not contain such consensus sequences. We have therefore investigated intracellular signaling triggered by LIF, measured LIF-induced changes in POMC gene transcription, and determined the POMC gene elements required for cytokine action.

\section{Methods}

Cell culture. AtT20 cells, obtained from the American Type Culture Collection (Rockville, MD), were grown in DME supplemented with $10 \%$ FCS, 2 mM L glutamine, streptomycin, and penicillin (all supplied by GIBCO BRL, Gaithersburg, MD. Human IgE myeloma cells, U266, were also obtained from American Type Culture Collection and were cultured in RPMI with $15 \%$ FCS, $2 \mathrm{mM}$ glutamine, streptomycin, and penicillin. Bacterially expressed, recombinant LIF and OSM were obtained from R \& D Systems, Inc. (Minneapolis, MD) and recombinant IL-6 was obtained from GIBCO BRL. Goat anti-human gp130 IgG and anti-LIF IgG were obtained from R \& D Systems, Inc. Polyclonal, rabbit anti-LIF (LIFR) receptor serum, raised against the soluble, extracellular portion of the LIFR was obtained from Immunex Corp. (Seattle, WA). ACTH assay was performed using a RIA kit purchased from Diagnostic Products Corp. (Los Angeles, CA). Intraassay variation was $4.9 \%$ at $152 \mathrm{pg} / \mathrm{ml}$, interassay variation was $6.4 \%$ at $134 \mathrm{pg} / \mathrm{ml}$.
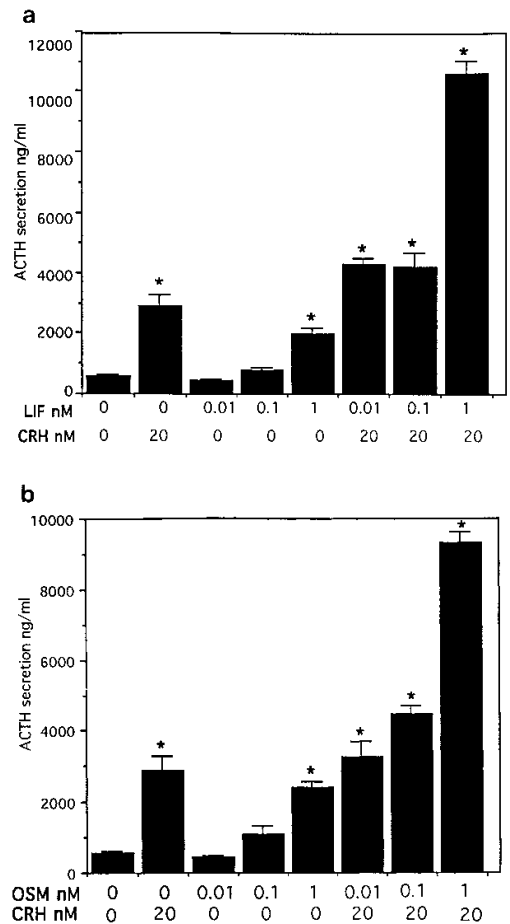

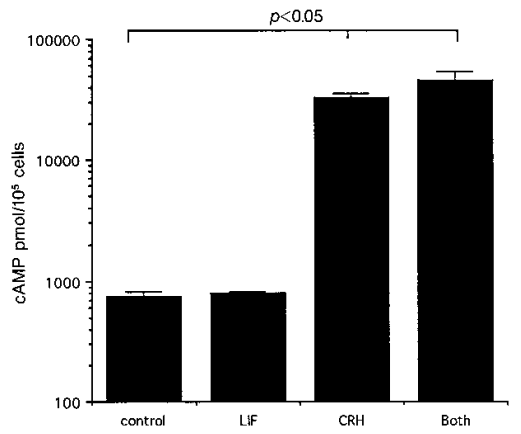

Figure 2. Effects of LIF and CRH on intracellular cAMP levels in AtT20 cells. Cells were serum starved for $24 \mathrm{~h}$, and then treated with $1 \mathrm{nM} \mathrm{LIF}, 10 \mathrm{nM}$ CRH, or both in the presence of $0.9 \mathrm{nM}$ isobutylmethylxanthine. Cells were harvested after $15 \mathrm{~min}$ and extracted with $95 \%$ ethanol: $0.1 \mathrm{~N} \mathrm{HCl}$.

cAMP was measured by RIA. The results are expressed as pmol cAMP/100,000 cells. Statistical comparison is by ANOVA, followed by Bonferonni $t$ test.

cAMP assay. AtT20 cells were cultured in serum-free medium for $24 \mathrm{~h}$ before treatment with LIF, corticotrophin-releasing hormone $(\mathrm{CRH})$, or both in the presence of $0.9 \mathrm{nM}$ isobutylmethylxanthine for $15 \mathrm{~min}$. Cells were washed in ice cold PBS and then extracted twice in ice cold $95 \%$ ethanol: $0.1 \mathrm{~N} \mathrm{HCl}$. The extracts were dried, then dissolved in assay buffer. The cAMP was measured using an RIA kit, Biotrak from Amersham Corp. (Arlington Heights, IL), according to the manufacturer's recommendations.

Immunoprecipitation and Western blotting. For immunoprecipitation with anti-ISGF3, cells were lysed in 1\% Triton X100 in buffer containing Tris $50 \mathrm{mM}, 150 \mathrm{mM} \mathrm{NaCl}, 50 \mathrm{mM} \mathrm{NaF}, 5 \mathrm{mM}$ sodium pyrophosphate, $1 \mathrm{mM}$ sodium orthovanadate, and $1 \mathrm{mM}$ phenylmethylsulphonylflouride (PMSF). Lysate was precleared with protein A-Sepharose (Pharmacia LKB Biotechnology Inc., Piscataway, NJ) for $1 \mathrm{~h}$ at $4^{\circ} \mathrm{C}$, then incubated with antiinterferon stimulated gene factor 3 (ISGF3) (Transduction Laboratories, Lexington, KY) overnight at $4^{\circ} \mathrm{C}$. Immune complexes were precipitated by addition of $5 \mu \mathrm{g}$ rabbit anti-mouse (Dako Corp., Carpinteria, CA) and $30 \mu \mathrm{l}$ of $50 \%$ protein A-Sepharose. The pellet was washed three times in ice cold lysis buffer and then eluted in $30 \mu 12 \times$ SDS-PAGE loading buffer by boiling for $5 \mathrm{~min}$.

For immunoprecipitation with antiSTAT 3, cells were lysed in boiling $1 \%$ SDS, $10 \mathrm{mM}$ Tris ( $\mathrm{pH}$ 7.4). Lysate was then diluted 1:10 in immunoprecipitation buffer consisting of $1 \%$ Triton X100, $150 \mathrm{mM}$ $\mathrm{NaCl}, 10 \mathrm{mM}$ Tris (pH 7.4), $1 \mathrm{mM}$ EDTA, 1 mM EGTA, $0.2 \mathrm{mM}$ sodium orthovanadate, $0.2 \mathrm{mM}$ PMSF, and $0.5 \%$ NP- $40.1 \mu \mathrm{g}$ of antiSTAT 3 was added and the tube rocked at room temperature for $1 \mathrm{~h}$. Immune complexes were precipitated with the addition of $5 \mu \mathrm{g}$ rabbit anti-mouse IgG (Dako Corp.) and $50 \mu 150 \%$ protein A-Sepharose. The pellet was washed three times in immunoprecipitation buffer, and then eluted in SDS-PAGE sample buffer.

The supernatant was loaded onto a 7.5\% SDS-PAGE gel for electrophoresis. The proteins were transferred to polyvinylidene difluoride (PVDF) membrane (Millipore Corp. Waters Chromotography, Milford, MA) in $25 \mathrm{mM}$ Tris (pH 8.3), $192 \mathrm{mM}$ glycine, and 20\% vol/ vol methanol at $400 \mathrm{~mA}$ for $1 \mathrm{~h}$. The membrane was blocked in $3 \%$ grade III ovalbumin (Sigma Chemical Co., St. Louis, MO), $150 \mathrm{mM}$ $\mathrm{NaCl}, 10 \mathrm{mM}$ Tris (pH 8.0), and $0.05 \%$ Tween. Antiphosphotyrosine detection used biotinylated PY20 in blocking buffer for $14 \mathrm{~h}$ at $4^{\circ} \mathrm{C}$. The membrane was washed in $150 \mathrm{mM} \mathrm{NaCl}, 10 \mathrm{mM}$ Tris $(\mathrm{pH} 8.0)$, and $0.05 \%$ Tween. Streptavidin-peroxidase conjugate (Amersham Corp.) was incubated with the membrane at 1:1,500 dilution with blocking buffer, and then, after further washes, detection was accomplished using ECL reagent as suggested by the manufacturer (Amersham Corp.).

To reprobe membrane, antibodies were stripped using $100 \mathrm{mM}$ betamercaptoethanol, $2 \%$ SDS, and $62.5 \mathrm{mM}$ Trip (pH 6.7) at $50^{\circ} \mathrm{C}$ for $30 \mathrm{~min}$.

Plasmids. Full length POMC-luc $(-706 /+64)$ was the kind gift of 
Dr. M. Low (Vollum Institute, OR). The (-323/-34)POMC-luc deletion was created by cutting the parent plasmid with Stu1 and Pst1 (GIBCO BRL), polishing the ends with Klenow (GIBCO BRL), and self-ligating with T4 ligase (GIBCO BRL). The (-323/-166)POMCluc deletion was created by cutting the parent plasmid with Stu1 and BssH11 (GIBCO BRL), polishing the ends with Klenow (GIBCO BRL), and self-ligating with T4 ligase (GIBCO BRL).

Transfection. Cells were plated in growth medium and allowed to adhere. Cells were then washed in serum and antibiotic-free medium and overlaid with DNA/lipofectamine (GIBCO BRL) mix. Routinely, $2 \mu \mathrm{g}$ DNA were used per well. Cells were incubated with DNA for $5 \mathrm{~h}$, then the medium was changed to DME supplemented with glutamine $2 \mathrm{mM}$ and BSA $0.1 \%$. Treatments were added after $16 \mathrm{~h}$, and cells harvested $6 \mathrm{~h}$ after that. Cells were washed in ice cold PBS, and then lysed in $25 \mathrm{mM}$ Tris phosphate ( $\mathrm{pH} 7.8$ ), $10 \mathrm{mM} \mathrm{MgCl}_{2}$, $0.1 \%$ BSA, $15 \%$ glycerol, $1 \%$ Triton X100, and 1 mM EDTA. $180 \mu \mathrm{l}$ of cleared cell lysate was used in a luciferase assay. Luciferase activity was measured in a Berthold Lumat LB 9501 luminometer (Wallac, Inc., Gaithersburg, MD) in the presence of $0.8 \mathrm{mM}$ ATP and $0.3 \mathrm{mM}$ D-luciferin. Integrated light emission over $15 \mathrm{~s}$ was measured. It was found in preliminary work that transfection efficiency varied less than $15 \%$ within a given experiment, as reported by others (31). Thus cotransfection of another reporter to control for transfection efficiency was not necessary. All transfections were repeated at least three times.

\section{Results}

$L I F$ related cytokines and $C R H$ synergise to stimulate $A C T H$ secretion in AtT20 cells. To determine the interaction of CRH with LIF, AtT20 cells were incubated for $24 \mathrm{~h}$ in the presence of increasing doses of LIF with CRH. As shown in Fig $1 a$, LIF induced ACTH secretion in a dose-dependent manner. $1 \mathrm{nM}$ LIF caused a fourfold induction in ACTH secretion after $24 \mathrm{~h}$. Although $\mathrm{CRH}(20 \mathrm{nM})$ alone induced the expected sevenfold induction of $\mathrm{ACTH}$, combination of the two compounds was synergistic with maximal doses of both agents together stimulating ACTH production 20-fold. Similarly, OSM induced

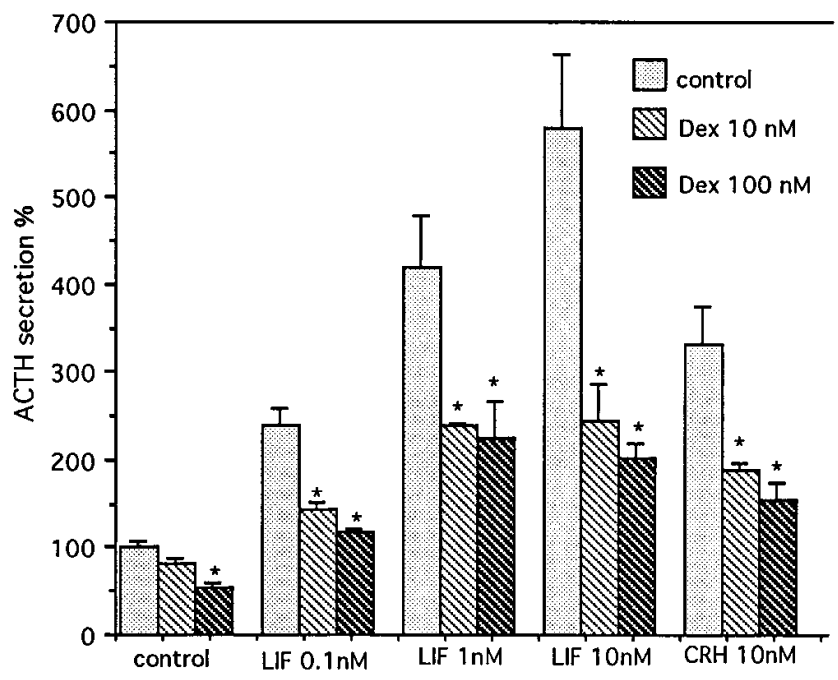

Figure 3. Dexamethasone inhibits LIF induction of ACTH secretion. AtT20 cells were serum starved for $24 \mathrm{~h}$ before being treated with dexamethasone for $48 \mathrm{~h}$, followed by addition of indicated peptide for another $24 \mathrm{~h}$. Results are expressed as percentage change relative to normalized control. LIF was used at $1 \mathrm{nM}, \mathrm{CRH}$ at $10 \mathrm{nM}$. Representative experiment performed in triplicate. *indicates $P<0.05 \mathrm{com}$ pared to control by ANOVA.

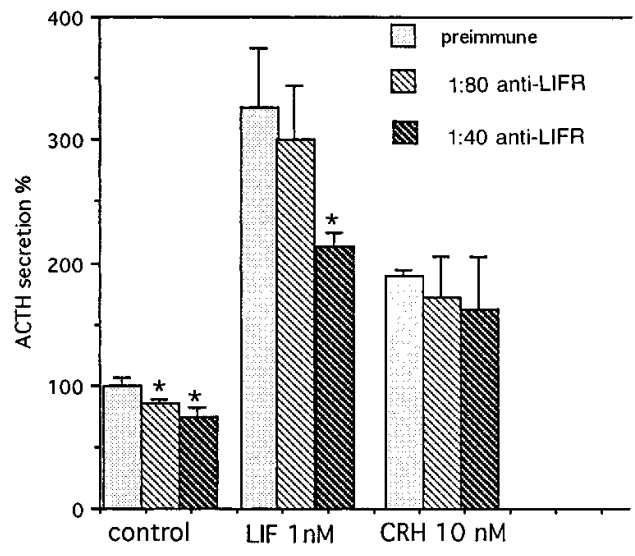

Figure 4. LIF-R antiserum attenuates LIF effects on ACTH secretion. AT20 cells were incubated with rabbit LIF-receptor antiserum or preimmune rabbit serum with or without the indicated compounds for $24 \mathrm{~h}$. Results are expressed as percent change over normalized control. Representative experiment performed in triplicate. *indicates $P<0.05$ compared to preimmune serum by ANOVA.

ACTH secretion 6-fold and, together with $\mathrm{CRH}$, resulted in a synergistic 18 -fold induction of peptide release (Fig. $1 \mathrm{~b}$ ). Furthermore, although cAMP levels increased over 40-fold within $15 \mathrm{~min}$ in response to CRH, LIF did not alter cAMP accumulation in these cells (Fig. 2). These results suggest that the synergy between CRH and LIF signaling on POMC does not occur at the level of cAMP accumulation.

Glucocorticoid inhibits LIF induction of ACTH secretion. As glucocorticoids suppress ACTH release and inhibit POMC gene transcription in pituitary corticotrophs (32), we examined modulation of ACTH secretion by LIF in the presence of dexamethasone. Pretreatment of AtT20 cells with 10 or $100 \mathrm{nM}$ dexamethasone effectively blocked $1 \mathrm{nM}$ LIF mediated induction of ACTH secretion and also inhibited $10 \mathrm{nM} \mathrm{CRH} \mathrm{stimu-}$ lation of ACTH as expected (Fig. 3). The inhibition of LIF action by dexamethasone was not overcome by $10 \mathrm{nM} \mathrm{LIF.}$

LIF activation and ACTH secretion. To determine whether the LIF effects on ACTH secretion were mediated by the low affinity LIF-transmembrane receptor, a series of incubations were performed in the presence of either LIF-R antiserum or preimmune rabbit serum. As expected, $1 \mathrm{nM}$ LIF significantly induced stimulation of ACTH during $24 \mathrm{~h}$ of incubation. In the absence of added LIF, the addition of LIFR antiserum (1:801:40) significantly inhibited basal ACTH concentrations $(P<$ 0.05), consistent with apparent interruption of an autocrine LIF-positive regulatory effect on ACTH secretion (Fig. 4). LIF-R antiserum (1:40) also attenuated $1 \mathrm{nM}$ LIF induction of ACTH production by approximately $35 \%(P<0.05)$. There was a modest, but not significant, effect of the specific antiserum on $\mathrm{CRH}$ induction of ACTH.

gp130 activation and ACTH secretion. To clarify the role of the gp130 receptor component in pituitary LIF signaling, we tested the effects of goat anti-human gp130 IgG. Due to limited cross-reactivity with the murine receptor, high concentrations of this $\mathrm{IgG}$ were used. Induction of ACTH secretion by both LIF and OSM, which are known to require gp130, was inhibited by coincubation with gp130 antibody (Fig. 5). The antiserum attenuated LIF- and OSM-induced ACTH secretion by 41 and $38 \%$, respectively $(P<0.05)$. Under these conditions, 


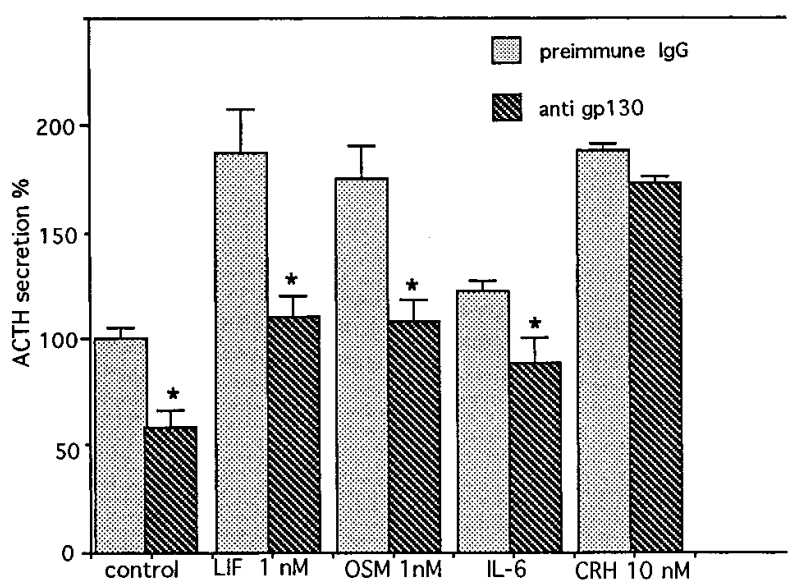

Figure 5. Anti-gp130 inhibits ACTH secretion. AtT20 cells were incubated with goat anti-gp130 IgG or normal goat IgG at $250 \mu \mathrm{g} / \mathrm{ml}$ and the indicated peptides for $24 \mathrm{~h}$. Results are expressed as percent change over normalized control. Representative experiment performed in triplicate. *indicates $P<0.05$ compared to normal IgG control by ANOVA.

and in the absence of added cytokine, basal ACTH release was inhibited by $42 \%(P<0.05)$, again consistent with an autocrine LIF effect on ACTH. In the presence of IL-6, which also signals through gp130, the antiserum also attenuated ACTH secretion by $28 \%$. A small and statistically insignificant $(8 \%)$ reduction in $\mathrm{CRH}$-induced stimulation by anti-gp130 possibly reflects loss of endogenously derived LIF synergy with exogenous CRH.

STAT $1 \alpha$ tyrosyl phosphorylation. As LIF signaling may be mediated by STAT proteins, we tested the activation of these substrates in LIF-treated AtT20 cells. LIF-induced tyrosyl phosphorylation of proteins immunoprecipitated with anti-STAT 1 was examined using the antiphosphotyrosine monoclonal antibody PY20 (Fig. 6 a). In these cells, LIFinduced phosphorylation of two principal proteins, one with the expected electrophoretic mobility of STAT $1 \alpha$ and the other migrating with a predicted molecular mass of $115 \mathrm{kD}$. A

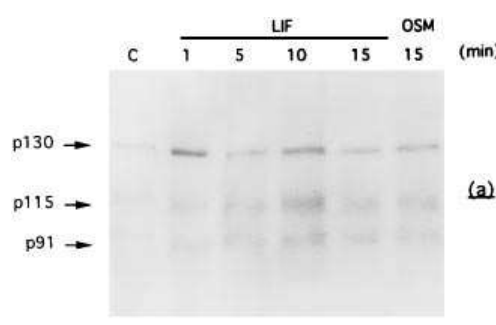

Figure 6. LIF induces tyrosyl phosphorylation of STAT 1 and p115 proteins in AtT20 cells. AtT20 cells were serum starved for $24 \mathrm{~h}$ before being treated with LIF (1 nM) or $\operatorname{OSM}(1 \mathrm{nM})$ for the indicated times before lysis and immunoprecipitation with anti-STAT 1, SDS-PAGE, and Western blotting with antiphosphotyrosine (a). The membrane was stripped and reprobed with anti-STAT $1(b)$ to

verify equal protein loading. Molecular weight was estimated against a prestained standard ladder from Amersham Corp. and is indicated. tyrosyl phosphorylated protein sized at approximately $130 \mathrm{kD}$ was also consistently observed and appeared to be phosphorylated under basal condition (Fig. 6, 7). Since JAK kinases migrate to approximately this position and are known to interact closely with STAT $1 \alpha$, we sought to examine whether p130 was a member of this kinase family. However, reprobing of the blots with antibodies to JAK-1, JAK-2, or Tyk-2 failed to detect this band (data not shown). Others have previously observed this band and attributed it to coimmunoprecipitated gp130 $(18,19)$.

After probing with PY20, the membranes were stripped and reprobed with anti-ISGF3, which recognizes both splice variants of the STAT 1 gene, STAT $1 \alpha$ and $1 \beta$. This showed equal loading of STAT 1 protein in each lane and confirmed the identity of the faster migrating band as STAT $1 \alpha$ (p91) (Fig. $6 \mathrm{~b}$ ). However, the $\mathrm{p} 115$ protein, although immunoprecipitated by anti-ISGF3, was not recognized by the same antibody after denaturation. The rapid induction of STAT phosphorylation observed by $1 \mathrm{~min}$, waned after $10 \mathrm{~min}$. The time course for phosphorylation of both STAT $1 \alpha$ and p115 occurred in parallel.

To confirm that the observed changes in STAT protein phosphorylation were due to the specific activity of LIF, we attempted to block this effect with anti-LIF serum. We used the titer of antiserum previously shown by us to block the effects of LIF on ACTH production (1:160) (8). The addition of LIF and preimmune serum caused a small, variable, additional induction of STAT protein phosphorylation, while the specific anti-LIF serum not only blocked this effect but reduced the phosphorylation state of both STAT $1 \alpha$ protein and p115 to that of quiescent, unstimulated cells (Fig. 7).

As OSM shares the gp130 subunit with LIF, and also stimulated POMC expression in AtT20 cells, the effects of OSM on STAT protein phosphorylation were examined. After $10 \mathrm{~min}$, OSM induced comparable induction of STAT 1 phosphorylation similar to that seen with LIF (Fig. 6, 7). In addition, the related $\mathrm{p} 115$ protein was similarly induced by OSM.

STAT 3 activation. LIF-R signaling is reported to result in phosphorylation of STAT 3 protein in addition to STAT $1 \alpha$ $(18,19)$. STAT 3 (or acute phase response factor was originally cloned as the $92-\mathrm{kD}$ protein tyrosyl phosphorylated in response to interferon (33). After treatments, cell lysis under denaturing conditions was performed since the STAT 3 antibody

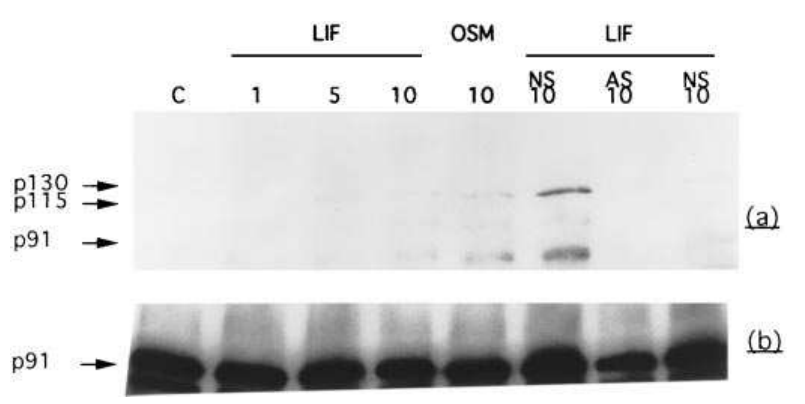

Figure 7. LIF induces tyrosyl phosphorylation of STAT 1 and p115 proteins in AtT20 cells. AtT20 cells were serum starved for $24 \mathrm{~h}$ before being treated with LIF $(1 \mathrm{nM})$ or OSM $(1 \mathrm{nM})$ either with or without normal $\operatorname{IgG}(N S)$ or antiLIF IgG $(A S)$ before lysis, immunoprecipitation with anti-STAT 1 , and Western blotting with antiphosphotyrosine $(a)$. The membrane was stripped and reprobed with antiSTAT $1(b)$. Estimated molecular weights are indicated. 


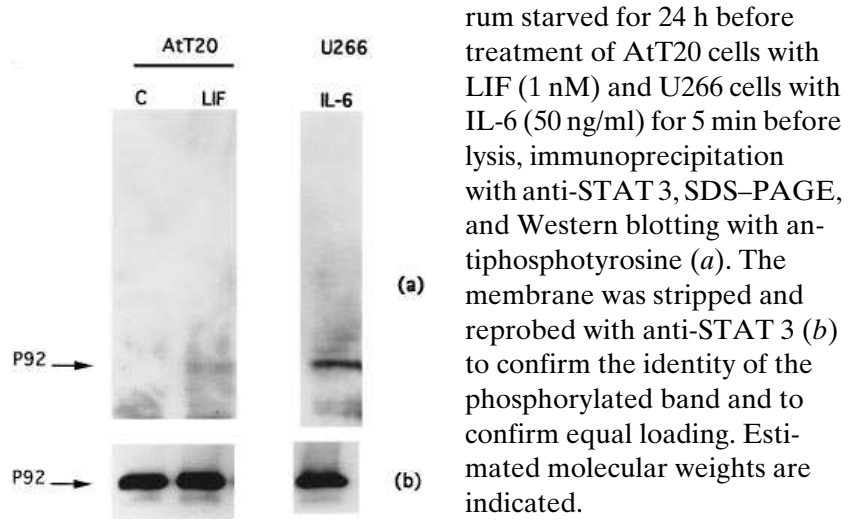

does not appear to recognize the native conformation of the molecule. LIF induced rapid tyrosyl phosphorylation of a protein band in AtT20 cells, which was also observed in the human, IL-6-responsive, myeloma cell line U266 (Fig. $8 a$ ). The identity of this band was confirmed by reprobing the blot with anti-STAT 3, depicted in Fig. $8 b$.

POMC transcription. To directly examine the effects of LIF on POMC gene transcription, a fragment of the rat POMC gene $-706 /+64$ fused to the luciferase reporter gene was transfected into AtT20 cells using lipofectamine. This region of POMC contains the elements required for pituitary expres-

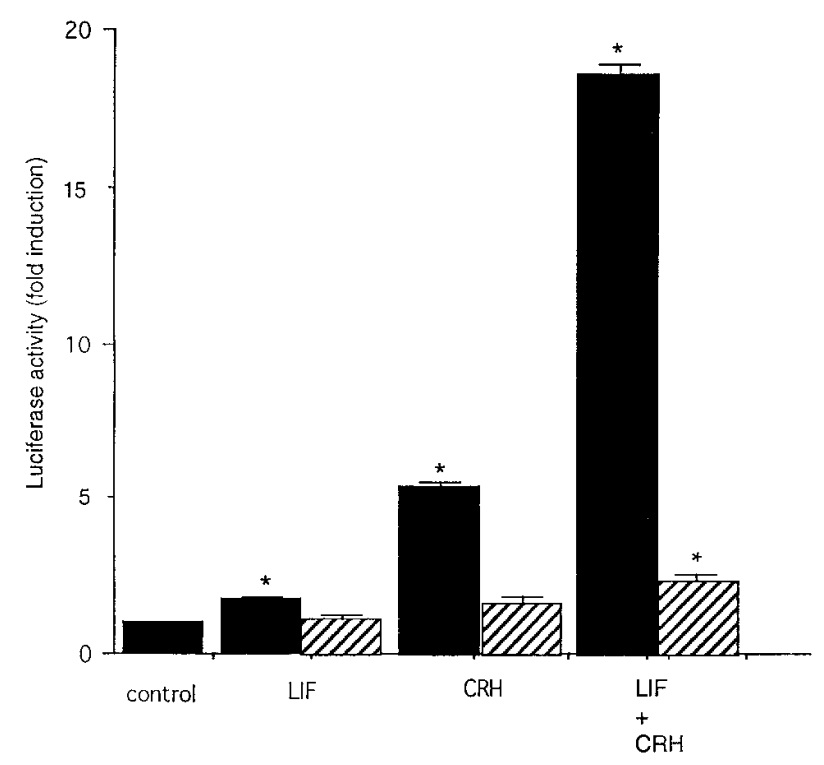

Figure 9. LIF and CRH effects on POMC transcription. POMC-luc $(-706 /+64)($ solid bars) or SV40-luc (diagonal striped bars) were transfected into AtT20 cells using lipofectamine. Cells were treated with vehicle (control), LIF (1 nM), CRH (10 nM), or both LIF $1 \mathrm{nM}$ and CRH $10 \mathrm{nM}$ in serum-free medium for $6 \mathrm{~h}$. Cells were then washed and harvested into lysis buffer. Results are expressed as fold induction of luciferase activity over control, mean of three wells \pm SD. * indicates $P<0.05$ compared to control.

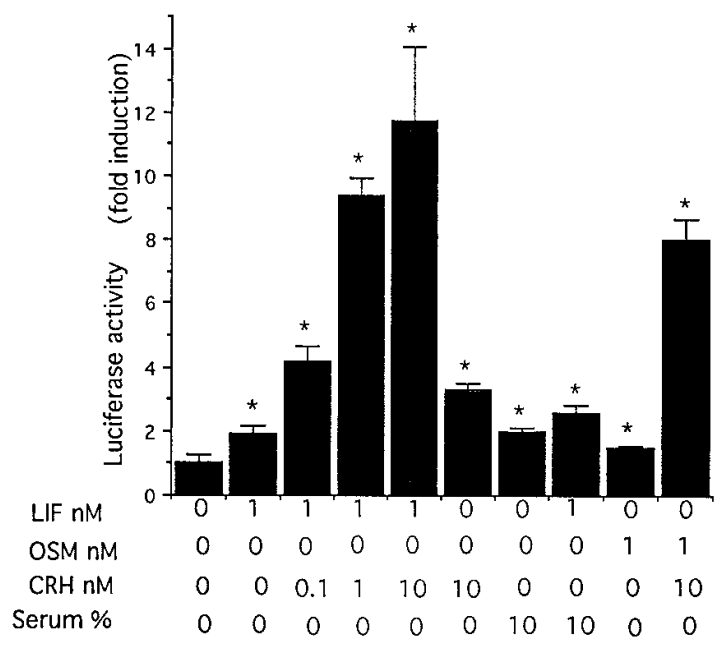

Figure 10. LIF, OSM, CRH, and serum effects on POMC transcription. POMC-luc $(-706 /+64)$ was transfected into AtT20 cells using lipofectamine. Cells were treated with LIF, OSM, CRH, or serum in the indicated concentrations in serum-free medium for $6 \mathrm{~h}$ before harvest. Results are expressed as fold induction of luciferase activity over control, mean of three wells \pm SD. *indicates $P<0.05$ compared to control.

sion of the gene and regulation both by $\mathrm{CRH}$ and glucocorticoid $(31,34) .1 \mathrm{nM}$ LIF exerted modest effects on luciferase expression, typically a twofold induction (Fig. 9-12). This effect was not significantly enhanced by the addition of serum to the incubation medium. CRH, as expected, stimulated expression of the reporter (5.4-fold). LIF exerted striking synergy with $10 \mathrm{nM}$ CRH in inducing reporter gene activity, with $1 \mathrm{nM}$ LIF enhancing the reporter from 5.4-18.6-fold (Fig. 9). This effect was seen over a range of $\mathrm{CRH}$ concentrations from $0.1-10$ $\mathrm{nM}$ (Fig. 10). The related cytokine oncostatin $\mathrm{M}$ at $1 \mathrm{nM}$ concentration also was a weak agonist of POMC transcription, enhancing reporter gene activity 1.6-fold (Fig. 10), but, together with $10 \mathrm{nM} \mathrm{CRH}$, increased reporter activity 10 -fold.

The major CRH-responsive region in the POMC reporter is located between -133 and -236 (35). Deletions of part $(-323 /-166)$ and all $(-323 /-34)$ of this region were performed in an attempt to more clearly delineate the element responsible for LIF action. Both deleted constructs were weaker than the intact promoter in driving POMC expression (Fig. 11). The more severe deletion $(-323 /-34)$ had only $23 \%$ of wild-type activity under basal, untreated conditions, while the more conservative deletion had activity reduced to $85 \%$ of wild type. both constructs exhibited markedly reduced LIF (1 $\mathrm{nM}$ ) responsiveness, 5 and $54 \%$ induction, respectively, and CRH (10 nM) responsiveness, 41 and $85 \%$ induction, comparable to a minimal SV40 promoter in the same plasmid (Fig. 9). However, both of these constructs exhibited enhanced transcription in response to the combination of CRH $(10 \mathrm{nM})$ and LIF (1 nM) (160 and 270\%, respectively) (Fig. 11).

To determine whether CRH synergy with LIF was dependent on activation of cAMP pathways, transfectants were treated with either 8 bromo cAMP or forskolin. Expression of the full-length POMC reporter was only induced 2.7 -fold by forskolin $5 \mu \mathrm{M}$, compared to 2.2-fold with LIF $1 \mathrm{nM}$ and 3.7fold with $\mathrm{CRH} 10 \mathrm{nM}$. Forskolin and 8 bromo cAMP were 


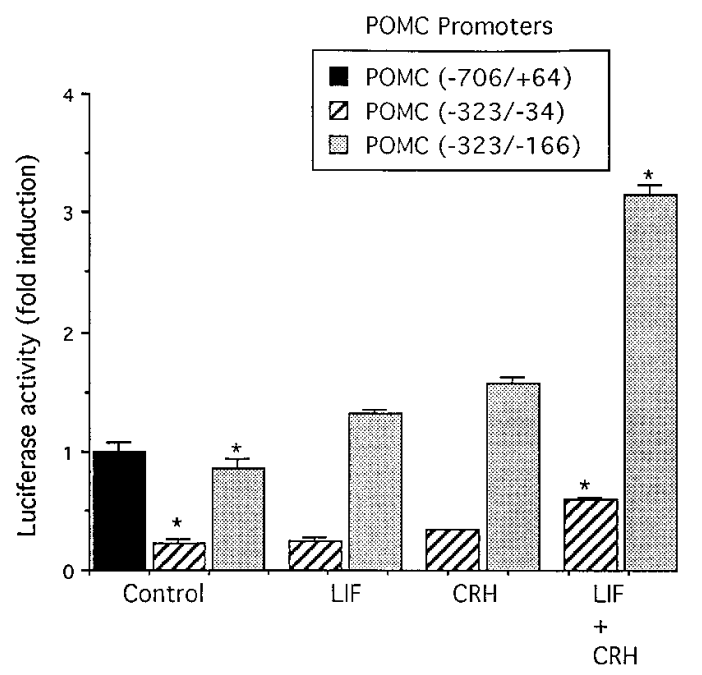

Figure 11. Basal activity and LIF responses of $(-323 /-34) \mathrm{POMC}-1 \mathrm{c}$ and $(-323 /-166)$ POMC-luc. Full-length POMC-luc $(-706 /+64)$ [solid bar], (-323/-34)POMC-luc [diagonal striped bars] or $(-323 /$ -166)POMC-luc [speckled bars] were transfected into AtT20 cells. Cells were grown in serum-free medium and harvested after $6 \mathrm{~h}$. Basal activity of the two deleted POMC constructs were compared to that of the full-length promoter (control). Also, the responses of the two deletion mutants to $1 \mathrm{nM} \mathrm{LIF}(L I F), 10 \mathrm{nM} \mathrm{CRH}(C R H)$, or both $\mathrm{LIF}$ and $\mathrm{CRH}(L I F+C R H)$ were measured and are compared to basal activity of the two constructs. Results are expressed as fold induction over control, mean of three wells \pm SD. * indicates $P<0.05$. POMC (-323/-34) and POMC (-323/-166) differ significantly from POMC $(-706 /+64)$ under control conditions. Combined LIF and CRH significantly enhanced both POMC $(-323 /-34)$ and $\operatorname{POMC}(-323 /-166)$ transcription.

consistently weaker agonists than $\mathrm{CRH}$ in this assay. However, $1 \mathrm{nM}$ LIF enhanced the effect of $5 \mu \mathrm{M}$ forskolin to 7.4-fold induction over control. Under the same conditions, $1 \mathrm{nM} \mathrm{LIF}$ enhanced the stimulation by $10 \mathrm{nM} \mathrm{CRH}$ from 3.7-fold over control to 14.6-fold over control (Fig. 12). Again, the cAMP agonists were consistently weaker than CRH even after LIF 1 $\mathrm{nM}$ addition.

\section{Discussion}

We originally identified LIF gene expression in human fetal pituitary tissue and demonstrated that LIF binding and immunoreactivity was predominantly associated with corticotroph cells (8). We have also shown LIF immunostaining in functional pituitary adenomas and demonstrated that murine AtT2 0 cells also express LIF mRNA and respond to LIF by increasing POMC gene expression (8). We now extend these observations by demonstrating that both LIF and OSM exert synergistic effects with $\mathrm{CRH}$ on POMC transcription. This induction of POMC by LIF is not explicable by augmenting $\mathrm{CRH}$ induction of cAMP. We also show that dexamethasone is a potent inhibitor, not only of CRH induction of ACTH secretion, but also of LIF action, suggesting distal convergence of these three signaling pathways, possibly at the level of the POMC gene.

The LIF-R is required to mediate LIF effects in AtT20 cells as evidenced by the immunoneutralization data shown above. These experiments also support the hypothesis that LIF is an

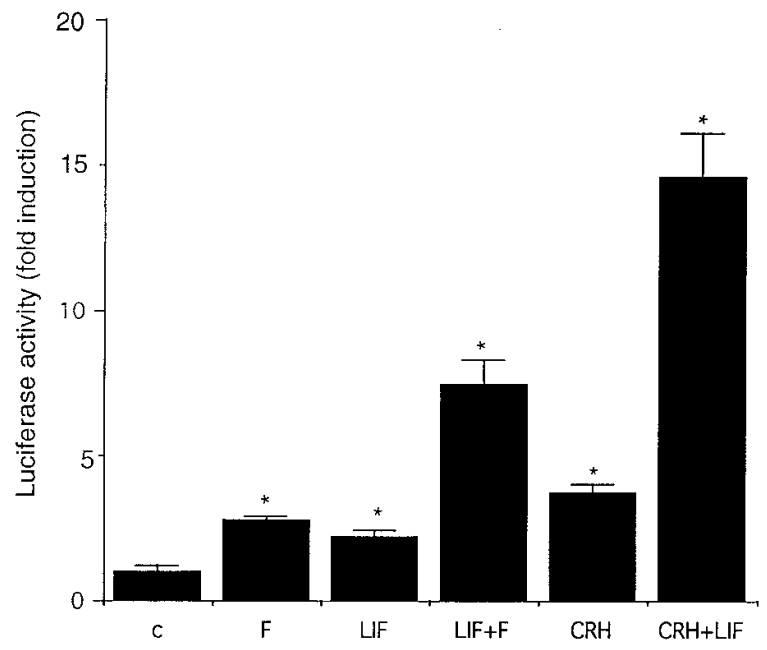

Figure 12. LIF, CRH, and forskolin effects on POMC transcription. Full-length POMC-luc $(-706 /+64)$ was transfected into AtT20 cells Cells were treated with $5 \mu \mathrm{M}$ forskolin $(F), 1 \mathrm{nM}$ LIF $(L I F)$, combination of forskolin and LIF $(L I F+F), 10 \mathrm{nM} \mathrm{CRH}(C R H)$, or CRH and LIF $(C R H+L I F)$. Results are expressed as fold induction of luciferase activity over vehicle-treated control cells, mean of three wells \pm SD. Representative experiment performed in triplicate. $*$ indicates $P<0.05$ compared to control.

important autocrine factor for sustaining basal ACTH production in AtT20 cells. Prolonged incubations with receptor antiserum exerted only slight effects on cell proliferation, excluding a direct cytotoxic effect, but LIF itself modestly inhibits cell number at concentrations greater than $1 \mathrm{nM}$ (data not shown). Further immunoneutralization experiments support the importance of the shared gp130 subunit in LIF and OSM signaling in AtT20 cells and also in mediating IL-6 effects. Both anti-LIFR and anti-gp130 caused small decreases in CRH stimulated ACTH production in the absence of added LIF. As discussed above, this latter observation probably reflects loss of autocrine LIF effects on ACTH secretion.

The LIF-related cytokine IL-6 has been shown to powerfully stimulate ACTH release in vivo (36), at least in part by a hypothalamic mechanism. It is possible that part of this observed effect may result from IL-6 stimulation of local pituitary LIF production.

The activated LIF-R complex is thought to recruit and activate two of the three JAK kinase family (17) and subsequently induce tyrosyl phosphorylation of STAT members (18). We now demonstrate a time-dependent induction of STAT $1 \alpha$ phosphorylation using antiphosphotyrosine antibody and also detect a larger protein species that was immunoprecipated by the anti-ISGF3 under nonreducing conditions. This larger protein may be coimmunoprecipitated and so represent a partner for STAT 1 or possibly reflect a shared epitope that is not recognized by the antibody after denaturation. As the epitope on STAT 1 is recognized by this antibody in both native and denatured conformations, the more probable hypothesis is that p115 is a discreet protein which coimmunoprecipitated with STAT $1 \alpha$ under these conditions. Furthermore, we also demonstrate STAT 3 tyrosyl phosphorylation induced by LIF in the AtT20 cells, supporting a hypothesis that multiple STAT family members are involved in mediating LIF effects in AtT20 cells. 
We demonstrate that LIF exerts a transcriptional effect on the $-706 /+64$ POMC gene fragment. It is possible that another cytokine-responsive element lies further upstream of the promoter fragment used (-706). In the presence of low concentrations of CRH, LIF exerts powerful effects on gene transcription driven by this promoter. Our data suggest that more than one region in the promoter may be responsible for mediating this effect. Certainly, abolishing $\mathrm{CRH}$ action by deletion of the principal CRH responsive element severely blunts the synergy of LIF with CRH, (from 18-fold induction to 3.6-fold), but it does not completely ablate it. This suggests that LIF/ $\mathrm{CRH}$ synergy may occur elsewhere within the gene. A functional AP-1 site has recently been described within the noncoding exon 1 of POMC (+44) (37). It is possible that LIF/ $\mathrm{CRH}$ action is partly mediated by this element, previously shown to be CRH responsive.

In summary, the murine AtT20 cells provide a useful model for studying LIF action on the pituitary corticotroph. Both gp130 and LIF-R components are required to mediate LIF and OSM actions on POMC expression in AtT20 cells. LIF signaling involved tyrosyl phosphorylation of STAT $1 \alpha$, STAT 3, and a novel p115 protein. These results, in conjunction with our earlier observations (8), ascribe a mechanism for cytokine-mediated regulation of ACTH. Thus, in addition to $\mathrm{CRH}$ and glucocorticoid, the LIF-related cytokines appear to participate in regulating POMC gene expression.

Recently, increasing evidence supports the existence of a network of distinct cytokines interfacing between the endocrine and immune systems and participating in neuroendocrine stress responses (38). Although we have also shown that LIF stimulates ACTH secretion in primary cultures of mouse pituitary (data not shown), it is unclear yet whether pituitary LIF action is solely paracrine or whether endocrine-derived LIF also participates in this immunopituitary interface. We have recently shown that in vivo pituitary LIF expression is regulated by LPS stress (Wang, Z., S.-G. Ren, and S. Melmed, manuscript submitted for publication). Thus, regarding neuroendocrine stress responses, if intracellular signaling events similar to those observed in AtT20 cells were to occur in vivo, they would provide a mechanistic explanation for continued activation of the hypothalamic-pituitary-adrenal axis in conditions of stress. The continued activation of this axis may be achieved through the LIF-mediated potentiation of CRH action so as to overcome increased glucocorticoid negative feedback at the level of the hypothalamus and pituitary. This may also explain the paradoxical fall in hypothalamic CRH concurrent with an increase in adenohypopyseal POMC observed in an animal model of chronic inflammatory disease (39).

\section{Acknowledgments}

Supported by National Institutes of Health grant DK42792 and by the Endocrine Fellows Foundation (D. Ray).

\section{References}

1. Jones, T.H., S. Justice, A. Price, and K. Chapman. 1993. Interleukin-6 secreting human pituitary adenomas in vitro. J. Clin. Endocrinol. \& Metab. 73: 207-209.

2. Arzt, E., G. Stelzer, U. Renner, M. Lange, O.A. Müller, and G.K. Stalla. 1992. Interleukin-2 and interleukin-2 receptor expression in human corticotrophic adenoma and murine pituitary cell cultures. J. Clin. Invest. 90:19441951.
3. Koenig, J.I., K. Snow, B.D. Clark, R. Toni, J.G. Cannon, A.R. Shaw, C.A. Dinarello, S. Reichlin, S.L. Lee, and R.M. Lechan. 1990. Intrinsic pituitary interleukin-1b is induced by bacterial lipopolysaccharide. Endocrinology. 126: 3053-3058.

4. Bernton, E.W., J.E. Beach, J.W. Holaday, R.C. Smallridge and H.C. Fein. 1987. Release of multiple hormones by a direct action of interleukin-1 on pituitary cells. Science (Wash. DC). 238:519-521.

5. Suda, T., F. Tozawa, T. Ushiyama, N. Tomori, T. Sumitomo, Y. Nakagami, M. Yamada, H. Demura, and K. Shizume. 1989. Effects of protein kinase-C related adrenocorticotrophin secretogogues and interleukin-1 on proopiomelanocortin gene expression in rat anterior pituitary cells. Endocrinology. 124: 1444-1449.

6. Spangelo, B.L., A.M. Judd, P.C. Isakson, and R.M. MacLeod. 1989. Interleukin-6 stimulates anterior pituitary hormone release in vitro. Endocrinology. 125:575.

7. Ferrara, N., J. Winer, and W.J. Henzel. 1992. Pituitary follicular cells secrete an inhibitor of aortic endothelial cell growth: identification as leukemia inhibitory factor. Proc. Natl. Acad. Sci. USA. 89:698-702.

8. Akita, S., J. Webster, S.G. Ren, H. Takino, J. Said, O. Zand, and S. Melmed. 1995. Human and murine pituitary expression of leukemia inhibitory factor: novel intrapituitary regulation of adrenocorticotropin synthesis and secretion. J. Clin. Invest. 95:1288-1298.

9. Davis, S., and G.D. Yancopoulos. 1993. The molecular biology of the CNTF receptor. Curr. Opin. Cell Biol. 5:281-285.

10. Stahl, N., and G.D. Yancopoulos. 1993. The alpha, betas, and kinases of cytokine receptor complexes. Cell. 74:587-590.

11. Kishimoto, T., T. Taga, and S. Akira. 1994. Cytokine signal transduction. Cell. 76:253-262.

12. Pennica, D., K.J. Shaw, T.A. Swanson, M.W. Moore, D.L. Shelton, K.A. Zioncheck, A. Rosenthal, T. Taga, N.F. Paoni, and W.I. Wood. 1995. Cardiotrophin-1 biological activities and binding to the leukemia inhibitory factor receptor/gp130 signalling complex. J. Biol. Chem. 270:10915-10922.

13. Gearing, D.P., M.R. Comeau, D.J. Friend, S.D. Gimpel, C.J. Thut, J. McGourty, K.K. Brasher, and J.A. King. 1992. The IL-6 signal transducer gp130: an oncostatin M receptor and affinity converter for the LIF receptor. Science (Wash. DC). 255:1434.

14. Gearing, D.P., C.J. Thut, T. VandenBos, S.D. Gimpel, P.B. Delaney, J. King, V. Price, D. Cosman, and M.P. Beckman. 1991. Leukemia inhibitory factor receptor is structurally related to the IL-6 signal transducer gp130. EMBO (Eur. Mol. Biol. Organ.) J. 10:2839-2848.

15. Davis, S., T.H. Aldrich, N. Stahl, L. Pan, T. Taga, Y. Kishimoto, N.Y. Ip, and G.D. Yancopoulos. 1993. LIFR beta and gp130 as heterodimerising signal transducers of the tripartite CNTF receptor. Science (Wash. DC). 260:18051808.

16. Davis, S., T.H. Aldrich, D.M. Valenzuela, V. Wong, M.E. Furth, S.P. Squinto, and G.D. Yancopoulos. 1991. The receptor for ciliary neurotrophic factor. Science (Wash. DC). 253:59-63.

17. Stahl, N., T.G. Boulton, T. Farruggella, N.Y. Ip, S. Davis, B.A. Witthuhn, F.W. Quelle, O. Silvennoinen, G. Barbieri, S. Pellegrini, J.N. Ihle, and G.D. Yancopoulos. 1994. Association and activation of JAK-Tyk kinases by CNTF-LIF-OSM-IL-6 beta receptor components. Science (Wash. DC). 263:9295 .

18. Lutticken, C., U.M. Wegenka, J. Yuan, J. Buschmann, C. Schindler, A. Ziemiecki, A.G. Harpur, A.F. Wilks, K. Yasukawa, T. Taga, et al. 1994. Association of transcription factor APRF and protein kinase Jak1 with the interleukin-6 signal transducer gp130. Science (Wash. DC). 263:89-92.

19. Campbell, G.S., D.J. Meyer, R. Raz, D.E. Levy, J. Schwartz, and C. Carter-Su. 1995. Activation of acute phase response factor (APRF)/STAT3 transcription factor by growth hormone. J. Biol. Chem. 270:3974-3979.

20. Fu, X.-Y. 1992. A transcription factor with SH2 and SH3 domains is directly activated by an interferon alpha-induced cytoplasmic protein kinase(s). Cell. 70:323-335.

21. Schindler, C., X.-Y. Fu, T. Improta, R. Aebersold, and J.E. Darnell. 1992. Proteins of transcription factor ISGF3: one gene encodes the p91 and p84kDa proteins that are activated by interferon alpha. Proc. Natl. Acad. Sci. USA. 89:7836-7839.

22. Schuai, K., C. Schindler, V.R. Prezioso, and J.E. Darnell. 1992. Activation of transcription by interferon gamma: tyrosine phosphorylation of a 91 kDa DNA binding protein. Science (Wash. DC). 258:1808-1812.

23. Gronowski, A.M., Z. Zhong, Z. Wen, M.J. Thomas, J. E. Darnell, and P. Rotwein. 1995. In vivo growth hormone treatment rapidly stimulates the tyrosine phosphorylation and activation of STAT-3. Mol. Endocrinol. 9:171-177.

24. David, M., E.F. Petricoin, K.-I. Igarashi, G.M. Feldman, D.S. Finbloom, and A.C. Larner. 1994. Prolactin activates the interferon-regulated p91 transcription factor and the JAK-2 kinase by tyrosine phosphorylation. Proc. Natl. Acad. Sci. USA. 91:7174-7178.

25. Witthuhn, B.A., F.W. Quelle, O. Silvennoinen, T. Yi, B. Tang, S. Miura, and J.N. Ihle. 1993. Jak2 associates with the erythropoietin receptor and is tyrosine phosphorylated and activated following stimulation with erythropoietin. Cell. 74:227-236.

26. Silva, C.M., H. Lu, M.J. Weber, and M.O. Thorner. 1994. Differential tyrosine phosphorylation of JAK1, JAK2 and STAT1 by growth hormone and 
interferon gamma in IM-9 cells. J. Biol. Chem. 269:27532-27539.

27. Shuai, K., G.R. Stark, I.M. Kerr, and J.E. Darnell. 1993. A single phosphotyrosine residue of STAT91 required for gene activation by interferongamma. Science (Wash. DC). 261:1744-1746.

28. Igarashi, K.-I., G. Garott, L. Ozmen, A. Ziemiecki, A.F. Wilks, A.G. Harpur, A.C. Larner, and D.S. Finbloom. 1994. Interferon gamma induces tyrosine phosphorylation of interferon gamma receptor and regulated association of protein tyrosine kinases, Jak1 and Jak2, with its receptor. J. Biol. Chem. 269: $14333-14336$.

29. Igarashi, K.-I., M. David, D.S. Finbloom, and A.C. Larner. 1993. In vitro activation of the transcription factor gamma interferon: evidence for a tyrosine phosphatase/kinase signalling cascade. Mol. Cell. Biol. 13:1634-1640.

30. Darnell, J.E., I.M. Kerr, and G.R. Stark. 1994. Jak-STAT pathways and transcriptional activation in response to IFNs and other extracellular signalling proteins. Science (Wash. DC). 264:1415-1421.

31. Boutellier, A.-M., P. Sassone-Corsi, and J.P. Loeffler. 1991. The protooncogene c-fos is induced by corticotropin-releasing factor and stimulates proopiomelanocortin gene transcription in pituitary cells. Mol. Endocrinol. 5: 1301-1310.

32. Clark, A.J.L., M.F. Stewart, P.M. Lavender, W.E. Farrell, S.R. Crosby, L. H. Rees, and A. White. 1990. Defective glucocorticoid regulation of proopiomelanocortin gene expression in a small cell lung cancer cell line. J. Clin. Endocrinol. Metab. 70:485-490.

33. Akira, S., Y. Nishio, M. Inoue, X.-J. Wang, S. Wei, T. Matsusaka, K. Yoshida, T. Sudo, M. Naruto, and T. Kishimoto. 1994. Molecular cloning of APRF, a novel interferon-stimulated gene factor3 p91-related transcription fac- tor involved in the gp130-mediated signaling pathway. Cell. 77:63-71.

34. Riegel, A.T., Y. Lu, J. Remenick, R.G. Wolford, D.S. Berard, and G.L. Hager. 1991. Proopiomelanocortin gene promoter elements required for constitutive and glucocorticoid-repressed transcription. Mol. Endocrinol. 5:19711982.

35. Jin, W.D., A.-M. Boutellier, M.J. Glucksman, S.R.J. Salton, J.-P. Loeffler, and J.L. Roberts. 1994. Characterization of a corticotropin-releasing hormone-responsive element in the rat proopiomelanocortin gene promoter and molecular cloning of its binding protein. Mol. Endocrinol. 8:1377-1388.

36. Mastorakos, G., J.S. Weber, A.-M. Magiakou, H. Gunn, and G.P. Chrousos. 1994. Hypothalamic-pituitary-adrenal axis activation and stimulation of systemic vasopressin secretion by recombinant interleukin-6 in humans potential implications for the syndrome of inappropriate vasopressin secretion. J. Clin. Endocrinol. \& Metab. 79:934-939.

37. Boutellier, A.-N.M., D. Maurer, D. Larang, J.R. Lundblad, J.L. Roberts, and J.P. Loeffler. 1995. Corticotropin-releasing hormone stimulates proopiomelanocortin transcription by c-fos dependent and independent pathways: characterization of an AP-1 site in exon. Mol. Endocrinol. 9:745-755.

38. Chrousos, G.P. 1995. The hypothalamic pituitary adrenal axis and immune-mediated inflammation. N. Engl. J. Med. 332:1351-1362.

39. Harbuz, M.S., R.G. Rees, D. Eckland, D.S. Jessop, D. Brewerton, and S.L. Lightman. 1992. Paradoxical responses of hypothalamic corticotropinreleasing factor (CRF) messenger ribonucleic acid (mRNA) and CRF-A1 peptide and adenohypophysical proopiomelanocortin mRNA during chronic inflammatory stress. Endocrinology. 130:1394-1400. 